\title{
Anticoagulant, Antiplatelet and Antianemic Effects of Citrus paradisi (Grape Fruit) Juice in Rabbits
}

\author{
Neelam Mallick ${ }^{1}$, Rafeeq Alam Khan ${ }^{2 *}$, Azra Riaz², Syeda Afroz ${ }^{2}$ \\ ${ }^{1}$ Department of Pharmacology, Ziauddin University, Karachi, Pakistan \\ ${ }^{2}$ Department of Pharmacology, Faculty of Pharmacy and Pharmaceutical Sciences, University of Karachi, Karachi, Pakistan \\ Email: ^rkhan1959@gmail.com
}

How to cite this paper: Mallick, N., Khan, R.A., Riaz, A. and Afroz, S. (2016) Anticoagulant, Antiplatelet and Antianemic Effects of Citrus paradisi (Grape Fruit) Juice in Rabbits. Pharmacology \& Pharmacy, 7, 397406

http://dx.doi.org/10.4236/pp.2016.71047

Received: August 14, 2016

Accepted: September 24, 2016

Published: September 27, 2016

Copyright $\odot 2016$ by authors and Scientific Research Publishing Inc. This work is licensed under the Creative Commons Attribution International License (CC BY 4.0).

http://creativecommons.org/licenses/by/4.0/

(c) (i) Open Access

\begin{abstract}
Medicinal plants are under continuous analysis worldwide to explore new medication to treat atherosclerosis and cardiovascular diseases. Citrus fruits have displayed utmost antioxidant activity, particularly flavonoids in Citrus paradisi have exhibited strong antioxidant and anti-inflammatory characteristics. This study was intended to examine effects of $C$. paradisi on blood coagulation and anticoagulation at doses of $0.1,0.3$ and $0.5 \mathrm{ml} / \mathrm{kg}$. Highly significant increase in thrombin time (TT) and substantial decline in fibrinogen $(\mathrm{Fb})$ level was noticed as related to control. There was substantial increase in TT, prothrombin time (PT) and activated partial thromboplastin time (aPTT) and noteworthy decrease in $\mathrm{Fb}$ level by warfarin. C. paradisi at 0.3 $\mathrm{ml} / \mathrm{kg}$ considerably inhibited aggregation of platelet by collagen, adenosine phosphate, arachidonic acid and epinephrine, while there was also substantial rise in Protein $\mathrm{C}$, TAT complex, RBC and hemoglobin concentration. In conclusion, these results suggest that the addition of $C$. paradisi to the diet of patients at risk of developing cardiovascular events could significantly decrease the morbidity or mortality in these patients due to high contents of phytochemicals like naringin, hesperidin, limonene and other flavonoids.
\end{abstract}

\section{Keywords}

Anticoagulant, Antiplatelet, Antianemic, Grape Fruit

\section{Introduction}

It has been documented that individuals consuming citrus fruits regularly have decreased risk of cardiovascular disease and ischemic stroke [1] [2]. Grapefruit is considered among the most widely consumed citrus fruits in the form of juice. The nutrients and bioactive phytochemicals present in grapefruit juice include sugars, organic acids, 
flavonoids and other phenolic compounds [3] [4].

Flavonoids are widely dispersed group of polyphenol compounds with health-related characteristics that are based on their antioxidant activity, e.g. inhibition of platelet aggregation, anticancer, anti-inflammatory and antiviral activities. The flavonoids present in Citrus are Flavanones, flavones, and flavonols, although flavones and flavonols are found in low concentrations as compared to flavanones, but are potent antioxidants and free radical scavengers [5].

Numerous unique threats have been proposed as probable measures for better revealing of subclinical atherosclerosis; however clinically attention has been paid to parameters like lipoprotein (a), apolipoprotein (apo) A-I, apo B-100, C-reactive protein (CRP) and fibrinogen to reveal risk factors for systemic atherosclerosis [6]. Moreover, it has been indefinite whether screening for some of these unique biomarkers significantly expands risk estimation over that related to standard lipid screening [7]-[9].

Most significant reasons for atherosclerosis and cardiovascular diseases are flaws in coagulation and thrombosis [10] [11]. Prevention and treatment of thrombogenic state have been investigated through coagulation and anticoagulant agents [12] [13]. Various factors of blood coagulation have been found to be associated with cardiovascular disease as well as hemostasis e.g. augmented level of factor VIII, von Willebr and factor and platelet activation [14].

The role of flavonoids and polyphenols has been studied to prevent and treat cardiovascular diseases due to several reasons [15] [16] including antioxidant and anti-inflammatory activity [17]-[19], as increase dietary intake of antioxidants may prevent atherosclerosis [20] [21], since increased cholesterol and occlusion is correlated [22][24].

Grape fruits (C. paradisi ) have high vitamin $\mathrm{C}$ and potassium and are worthy source of calcium, folate, iron and other minerals. They also hold protective plant chemicals like phenolic acid, limonoids, monoterpenes, terpenes and bioflavonoids that are prevents cancer and heart diseases. Naringin is the chief bioflavonoid in grapefruit having diverse pharmacological affects e.g. antioxidant, hypolipidemic [25] [26] and anticarcinogenic activity [5].

Recently, thrombin has been found to have dual role and all the anti-inflammatory effects of grape fruits contribute towards anti-coagulant state in the body [27] [28]. Thus current study was aimed to measure anticoagulant, hematological and antithrombotic effects of $C$. paradisi to endorseits preventive and therapeutic role in various situations; hence thrombin and prothrombin time, activated partial thromboplastin time (aPTT), fibrinogen level $(\mathrm{Fb})$, platelet function, thrombin antithrombin (TAT) complex and protein $\mathrm{C}$ (PC) were determined to evaluate the effects of these parameters on blood in rabbits.

\section{Materials and Methods}

\subsection{Citrus paradisi Juice}

Grapefruit (C. paradisi) was bought from the local vendors. The fruit was recognized by 
Prof. Anjum Parveen (Director, Plant Conservation Center; University of Karachi) and voucher sample no C.P 09-10 was deposited in the Department of Pharmacognosy, University of Karachi. The fruit was peeled and pressed to obtain fresh juice which was used promptly after filtration. The fresh juice was then given by mouth in three doses i.e. $0.1,0.3$ and $0.5 \mathrm{ml} / \mathrm{kg}$ as per body weight of the animals.

\subsection{Animals}

Study was conducted on 60, healthy white rabbits of either sex with average body weight $1300 \pm 50$ grams after agreement from board of advance studies and research, University of Karachi. Steel rod bottom cages were used for individual housing of the rabbits with unrestricted contact to diet and water at a temperature $23^{\circ} \mathrm{C} \pm 2^{\circ} \mathrm{C}$, humidity 50\% - 60\% with 12 hour light/dark cycle.

\subsection{Dosing}

Animals were allocated in 6 groups having 10 rabbit's each. $C$. paradisi was administered to three groups in the doses of $0.1,0.3$ and $0.5 \mathrm{ml} / \mathrm{kg}$ respectively for 30 days. Animal group served as normal control received saline in doses equivalent to their body weights, while remaining two groups received standard drugs aspirin and warfarin. Aspirin was administered on once daily basis $(150 \mathrm{mg} / \mathrm{kg})$ suspended in normal saline for 6 days per week [29], warfarin was given for 6 days only in distilled water i.e. $5 \mathrm{mg} / \mathrm{kg}$ first 3 days and $10 \mathrm{mg} / \mathrm{kg}$ next 3 days [30]. Drugs and juices were administered via gastric intubation. 3. Prepare Your Paper before Styling.

\subsection{Sample Collection}

The National Committee for Clinical Laboratory Standards (NCCLS) approved guidelines H21-A3 were followed for Sample collection and handling [31]. Blood samples were gathered in EDTA and 3.8\% tri sodium citrate containing tubes in the ratio of 9:1 and gel tubes at the end of dosing period from ear vein. Centrifugation of Blood samples was done to separate plasma at $2000 \mathrm{x} g$ for $10 \mathrm{~min}$ in Humax $14 \mathrm{~K}$ (Human, Germany).

\subsection{Coagulation and Hematological Testing}

Coagulation parameters were determined by Huma clot duo (Human, Germany) using standard reagent kits provided by Human, Germany. Turbidimetric clot were detected and coagulation endpoint was assessed in plasma. $100 \mathrm{ul}$ thrombin reagent was used to incubate $200 \mathrm{ul}$ plasma for TT; $100 \mathrm{ul}$ plasma with $200 \mathrm{ul}$ pre-warmed thromboplastin reagent was incubated for $\mathrm{PT}$. While $100 \mathrm{ul}$ plasma was incubated for 1 to $2 \mathrm{~min}$ at $37^{\circ} \mathrm{C}$ with $100 \mathrm{ul}$ aPTT-EL reagent then $100 \mathrm{ul} \mathrm{CaCl} 2$ was added for activated partial thromboplastin time. All plasma samples were incubated at $37^{\circ} \mathrm{C}$ for $3 \mathrm{~min}$. Clauss method [32] was used to evaluate $\mathrm{Fb}$ concentration as defined by McNerlan et al. [33].

Fully automated hematology analyzer, Huma Count (Human, Germany) was employed to study hematological parameters i.e. red blood cell count (RBC), white blood 
cell count (WBC), platelet count (PLT), Hematocrit (Ht), hemoglobin (Hb), mean corpuscular volume (MCV) and mean corpuscular hemoglobin $(\mathrm{MCH})$.

Helena Agg RAM aggregometer (Helena Laboratories Corp, Beaumont, TX, USA) was used for the assay of platelet aggregation. Plasma separated from blood was considered as platelet rich plasma (PRP), how-ever further centrifugation of blood for 10 15 minutes at 1600 - $2000 \mathrm{rpm}$ yielded platelet-poor plasma (PPP). Standardization of

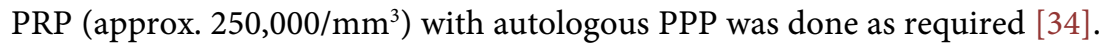

Platelet reactivity was found at $37^{\circ} \mathrm{C}$ for $10 \mathrm{~min}$ [35], for untreated PRP mixed with the aggregation reagent, the absorbance represents $0 \%$ aggregation; the absorbance denotes $100 \%$ of PPP control. Epinephrine $(300 \mu \mathrm{M})$, Arachidonic acid $(500 \mu \mathrm{g} / \mathrm{ml})$, Adenosine diphosphate $(20 \mu \mathrm{M})$ and Collagen $(10 \mu \mathrm{g} / \mathrm{ml})$, were used as platelet aggregation inducers. Platelet aggregation in samples was measured as described by Riaz et al. [36]. Pipette was used to measure and pour $450 \mu \mathrm{l}$ PRP into cuvettes which were then incubated at $37^{\circ} \mathrm{C}$. PPP cuvette was inserted into suitable channel and set to $100 \%$ aggregation; $50 \mu \mathrm{l}$ of aggregation inducing substance was then added. Change in light transmission was considered as resulted aggregation and expressed as \% PPP transmission.

The activity of PC and TAT complex in plasma was assessed by commercial Protein $\mathrm{C}$ and TAT complex Elisa kit (Cusabio Biotech Co. LTD). Standard plasma was used for the preparation of standard curves and absorbance was observed at $450 \mathrm{~nm}$. The activity of TAT complex and Protein $\mathrm{C}$ in the samples was stated as percentage related to the level of activity of standard plasma. All the tests were performed following NCCL guidelines.

\subsection{Statistical Analysis}

Software package for statistical analysis (SPSS) version 17 was employed for Data entry and analysis presenting the data as mean \pm S. E. M with $95 \%$ confidence interval. ANOVA followed by post hoc was executed for the comparisons of values with control. The Values of $\mathrm{p} \leq 0.05$ denote significant and $\mathrm{p} \leq 0.005$ denote highly significant results.

\section{Results}

The results of $C$. paradisi juice and warfarin on TT, PT, aPTT and Fb are shown in Table 1 . There was substantially high increase in TT and significant increase in aPTT, however there was noteworthy decrease in $\mathrm{Fb}$ level at $0.3 \mathrm{ml} / \mathrm{kg}$ of $C$. paradisias compared to control. However warfarin caused substantially high increase in TT, PT and aPTT and significantly reduced Fb level.

Table 2 displays result of $C$. paradisi on aggregation of platelet. There was considerable inhibition in aggregation of platelet by collagen (Col), adenosine phosphate (ADP), arachidonic acid (AA) and epinephrine (Epi) at $0.3 \mathrm{ml} / \mathrm{kg}$ dose of $C$. paradisi. However at $0.5 \mathrm{ml} / \mathrm{kg}$ only AA revealed significant inhibition in platelet aggregation.

Table 3 shows results of $C$. paradisi in different doses on Protein C and TAT complex. There was considerable rise in Protein $C$ and TAT complex at $0.3 \mathrm{ml} / \mathrm{kg}$, while 
Table 1. Effects of warfarin and C. paradisi on coagulation factors.

\begin{tabular}{ccccc}
\hline \multirow{2}{*}{ Group/Dose $\mathrm{ml} / \mathrm{kg}$} & \multicolumn{4}{c}{ Parameters } \\
\cline { 2 - 5 } & $\mathrm{TT}(\mathrm{Sec})$ & $\mathrm{PT}(\mathrm{Sec})$ & $\mathrm{aPTT}(\mathrm{Sec})$ & $\mathrm{Fb}(\mathrm{mg} / \mathrm{dl})$ \\
\hline Control & $9.55 \pm 0.42$ & $5.11 \pm 0.06$ & $8.18 \pm 0.05$ & $438.75 \pm 42.38$ \\
C. paradisi $(0.1)$ & $9.20 \pm 0.13$ & $5.22 \pm 0.02$ & $12.51 \pm 1.82$ & $407.07 \pm 28.65$ \\
C. paradisi (0.3) & $12.41 \pm 0.58^{* *}$ & $6.35 \pm 0.73$ & $11.46 \pm 0.31^{*}$ & $333.10 \pm 29.55^{\star}$ \\
C. paradisi (0.5) & $8.81 \pm 0.08$ & $5.85 \pm 0.04$ & $8.68 \pm 0.11$ & $380.24 \pm 32.61$ \\
Warfarin & $16.57 \pm 1.74^{* *}$ & $13.60 \pm 1.73^{* *}$ & $15.74 \pm 1.77^{* *}$ & $315.39 \pm 25.54^{\star}$
\end{tabular}

Values, mean \pm S.E.M. ${ }^{*} \mathrm{P} \leq 0.05$ significantly unlike as compared to control ${ }^{* *} \mathrm{P} \leq 0.005$ unlike extremely significant as compared to control Warfarin: $5 \mathrm{ml} / \mathrm{kg}$ (first three days) and $10 \mathrm{mg} / \mathrm{kg}$ (another 3 days).

Table 2. Effects of $C$. paradisi on aggregation of platelet.

\begin{tabular}{ccccc}
\hline \multirow{2}{*}{ Group/Dose ml/kg } & \multicolumn{4}{c}{ parameters } \\
\cline { 2 - 5 } & $\mathrm{ADP}(20 \mu \mathrm{M})$ & $\mathrm{Col}(10 \mu \mathrm{g} / \mathrm{ml})$ & $\mathrm{Epi}(300 \mu \mathrm{M})$ & $\mathrm{AA}(500 \mu \mathrm{g} / \mathrm{ml})$ \\
\hline Control & $53.85 \pm 5.36$ & $18.20 \pm 1.15$ & $13.89 \pm 0.97$ & $60.84 \pm 8.38$ \\
C. paradisi (0.1) & $44.45 \pm 0.97$ & $22.52 \pm 1.95$ & $11.78 \pm 1.31$ & $61.69 \pm 8.51$ \\
C. paradisi (0.3) & $32.40 \pm 0.58^{*}$ & $10.35 \pm 0.75^{\star}$ & $9.38 \pm 0.49^{*}$ & $48.20 \pm 7.31^{*}$ \\
C. paradisi (0.5) & $42.96 \pm 0.75$ & $21.75 \pm 1.94$ & $13.01 \pm 2.63$ & $49.71 \pm 5.87^{*}$ \\
Aspirin & $32.29 \pm 0.71^{*}$ & $10.44 \pm 0.78^{*}$ & $12.84 \pm 1.53$ & $24.51 \pm 1.18^{* *}$ \\
\hline
\end{tabular}

Values, mean \pm S.E.M. ${ }^{*} \mathrm{P} \leq 0.05$ significantly unlike as compared to control ${ }^{* *} \mathrm{P} \leq 0.005$ unlike extremely significant as compared to control $\mathrm{ADP}=$ Adenosine diphosphate; $\mathrm{Col}=$ Collagen; $\mathrm{Epi}=$ Epinephrine; $\mathrm{AA}=$ Arachidonic acid .

Table 3. Impact of $C$. paradisi on protein c and TAT complex.

\begin{tabular}{ccc}
\hline \multirow{2}{*}{ Group/Dose $\mathrm{ml} / \mathrm{kg}$} & \multicolumn{2}{c}{ parameters } \\
\cline { 2 - 3 } & Protein C & TAT complex \\
\hline Control & $32.08 \pm 0.81$ & $2.36 \pm 0.15$ \\
C. paradisi $(0.1)$ & $36.25 \pm 1.59$ & $2.71 \pm 0.14^{\star}$ \\
C. paradisi $(0.3)$ & $38.96 \pm 1.48^{\star}$ & $3.25 \pm 0.07^{\star}$ \\
C. paradisi $(0.5)$ & $33.35 \pm 2.23$ & $2.71 \pm 0.14$ \\
\hline
\end{tabular}

Values, mean \pm S.E.M. ${ }^{*} \mathrm{P} \leq 0.05$ significantly dissimilar as compared to control.

there was no significant change in Protein $\mathrm{C}$ and TAT complex at $0.1 \mathrm{ml} / \mathrm{kg}$ and 0.5 $\mathrm{ml} / \mathrm{kg}$.

Table 4 shows results of $C$. paradisi on hematology; at $0.3 \mathrm{ml} / \mathrm{kg}$ considerable rise in $\mathrm{RBC}$ and hemoglobin was observed, while at $0.5 \mathrm{ml} / \mathrm{kg}$ only significant rise in $\mathrm{RBC}$ was seen whereas at $0.1 \mathrm{ml} / \mathrm{kg}$ no significant change in any hematological factors was observed. However WBC, PLT, hematocrit and mean corpuscle volume were not influenced by any dose of $C$. paradisi. 
Table 4. Effect of $C$. paradisi and aspirin on hematological parameters.

\begin{tabular}{cccccccc}
\hline \multirow{2}{*}{$\begin{array}{c}\text { Group/Dose } \\
\mathrm{ml} / \mathrm{kg}\end{array}$} & $\begin{array}{c}\mathrm{RBC} \\
\left(\mathrm{x} 10^{5} / \mathrm{cm}\right)\end{array}$ & $\begin{array}{c}\mathrm{WBC} \\
\left(\mathrm{x} 10^{5} / \mathrm{cm}\right)\end{array}$ & $\begin{array}{c}\mathrm{PLT} \\
\left(\mathrm{x} 10^{3} / \mathrm{cm}\right)\end{array}$ & $\begin{array}{c}\mathrm{Hb} \\
(\mathrm{g} / \mathrm{dl})\end{array}$ & $\begin{array}{c}\mathrm{Ht} \\
(\%)\end{array}$ & $\begin{array}{c}\mathrm{MCV} \\
(\%)\end{array}$ & $\begin{array}{c}\mathrm{MCH} \\
(\mathrm{Pg} / \mathrm{cell})\end{array}$ \\
\hline Control & $3.84 \pm 0.3$ & $3.32 \pm 0.4$ & $291.04 \pm 27.6$ & $9.77 \pm 0.4$ & $28.23 \pm 4$ & $62.4 \pm 0.7$ & $19.5 \pm 0.6$ \\
\hline C. paradisi $(0.1)$ & $4.68 \pm 0.4$ & $4.14 \pm 0.4$ & $283.10 \pm 36.7$ & $9.90 \pm 0.2$ & $30.21 \pm 3$ & $61.6 \pm 0.7$ & $20.6 \pm 0.6$ \\
\hline C. paradisi (0.3) & $4.95 \pm 0.3^{*}$ & $5.90 \pm 0.4$ & $298.70 \pm 29.9$ & $11 \pm 0.5^{*}$ & $32.38 \pm 2$ & $62.3 \pm 0.5$ & $19.7 \pm 0.6$ \\
\hline C. paradisi $(0.5)$ & $4.82 \pm 0.3^{*}$ & $4.26 \pm 0.3$ & $294.10 \pm 27.7$ & $10.01 \pm 0.2$ & $33.95 \pm 3$ & $61.9 \pm 0.8$ & $20.2 \pm 0.7$ \\
\hline Aspirin & $3.64 \pm 0.4$ & $3.77 \pm 0.3$ & $281.6 \pm 32.4$ & $5.28 \pm 0.2$ & $20.6 \pm 0.5$ & $63.5 \pm 0.7$ & $21.7 \pm 0.8^{*}$ \\
\hline
\end{tabular}

Values, mean \pm S.E.M. ${ }^{*} \mathrm{P} \leq 0.05$ significantly unlike as compared to control Aspirin: $150 \mathrm{mg} / \mathrm{kg}$ once daily for 6 days a week.

\section{Discussion}

This research was planned particularly to study the effectiveness of $C$. paradisi on coagulation factors. Dietary flavonoid is one of the herbal components which may alter coagulation and fibrinolysis. It is known that dietary lipids may alter factor VII [37], fibrinogen, plasminogen activator and tissue plasminogen [38].

The risk of bleeding may better be defined by coagulation assay like PT, TT, aPTT and $\mathrm{Fb}$ [39]. The effect of $C$. paradisi juice was thus determined at different doses on platelet count, activated partial thromboplastin time, thrombin time, prothrombin time, and fibrinogen concentration, since these parameters can better define the risk of bleeding [40], hence were utilized to observe the efficacy of $C$. paradisi on coagulation process as well as their efficacy in CVD.

Hepatic synthesis of clotting factors stimulated by increased catabolic rate of prothrombin, results in increased plasma concentration of clotting factors [41]. Therefore it may be concluded that increased concentration of cholesterol may lead to increased plasma concentration of coagulation factors or vice versa.

One possible explanation of prolonged aPTT could be cholesterol lowering effect of flavonoids and other components. Moreover current investigation revealed remarkable inhibition of platelet aggregation by $C$. paradisi stimulated by collagen, adenosine diphosphate, arachidonic acid and epinephrine, hence $C$. paradisi seems to be more effective against thrombosis since existing antiplatelet agents only inhibit thromboxane A2 or ADP platelet activation pathways without interfering number of other platelet activation pathways that may contribute to thrombotic event [42].

C. paradisi may have anticoagulant effect due to inhibition of intrinsic coagulation factor and thrombin, since factor IX and $\mathrm{X}$ are essentially required for thrombin generation [28]. There is evidence that deficiency of PC and TAT complex leads to cardiovascular events [10] [42] [43]. While present outcomes reveals raise in PC and TAT complex, which may lead to inhibition of thrombin activity, prolongation of TT and decrease $\mathrm{Fb}$. hence it may be concluded that $C$. paradisi may have a beneficial effect in thrombotic disease patients.

Our result also revealed significant rise in hemoglobin and $\mathrm{RBC}$ as compared to control, 
these beneficial effects of C. paradisi may be due to the presence of flavonoids (hesperidin hesperetin and nobiletin), vitamin C, pyridoxine and iron in citrus fruits reported in several studies [15] [17] [44]-[48].

\section{Conclusions}

Normal blood flow depends on the balance between pro-coagulant and anti-coagulant factors, unless this balance is shifted towards pro-coagulant mechanisms due to injury or increased vascular sclerosis. Thus present results show that grape fruit juice can act as an effective anticoagulant as it keeps the balance shifted towards anti-coagulant mechanisms.

These results suggest that addition of $C$. paradisi juice may be tested by adding to the diet of patients at risk of developing cardiovascular or neurovascular events and may also be helpful in improving the general health of these patients due to high contents of vitamin C, B and phytochemicals such as carotenoids, flavonoids and limonoids.

\section{Acknowledgements}

Authors are thankful to technical staff Department of Pharmacology, University of Karachi for their support during the study.

\section{Conflict of Interest Statement}

None of the author involved in the study has received any financial assistance from any organization and there is no conflict of interest to declare.

\section{References}

[1] Dauchet, L., Amouyel, P., Hercberg, S. and Dallongeville, J. (2006) Fruit and Vegetable Consumption and Risk of Coronary Heart Disease: A Meta-Analysis of Cohort Studies. Journal of Nutrition, 136, 2588-2593.

[2] Johnsen, S.P., Overvad, K., Stripp, C., Tjønneland, A., Husted, S.E. and Sørensen, H.T. (2003) Intake of Fruits and Vegetables and the Risk of Ischemic Stroke in a Cohort of Danish Men and Women. The American Journal of Clinical Nutrition, 78, 57-64.

[3] Zhang, M., Duan, C., Zang, Y., Huang, Z. and Liu, G. (2011) The Flavonoid Composition of Flavedo and Juice from the Pummelo Cultivar Citrus grandis (L.) Osbeck and the Grapefruit Cultivar Citrus paradise from China. Food Chemistry, 129, 1530-1536. http://dx.doi.org/10.1016/j.foodchem.2011.05.136

[4] Kelebek, H. (2010) Sugars, Organic Acids, Phenolic Compositions and Antioxidant Activity of Grapefruit Citrus paradisi Cultivars Grown in Turkey. Industrial Crops and Products, 32, 269-274. http://dx.doi.org/10.1016/j.indcrop.2010.04.023

[5] Armando, C., Maythe, S. and Beatriz, N.P. (1998) Antioxidant Activity of Grapefruit Seed Extract on Vegetable Oils. Journal of the Science of Food and Agriculture, 77, 463-467. http://dx.doi.org/10.1002/(SICI)1097-0010(199808)77:4<463::AID-JSFA62>3.0.CO;2-1

[6] Ridker, P.M., Stampfer, M.J. and Rifai, N. (2001) Novel Risk Factors for Systemic Atherosclerosis: A Comparison of C-Reactive Protein, Fibrinogen, Homocysteine, Lipoprotein(a), and Standard Cholesterol Screening as Predictors of Peripheral Arterial Disease. JAMA, 285, 2481-2485. http://dx.doi.org/10.1001/jama.285.19.2481 
[7] Ridker, P.M. (1999) Evaluating Novel Cardiovascular Risk Factors. Ann Intern Med., 130, 933-937. http://dx.doi.org/10.7326/0003-4819-130-11-199906010-00018

[8] Smith, S.C., Greenland, P. and Grundy, S. (2000) Beyond Secondary Prevention: Identifying the High-Risk Patient for Primary Prevention: Executive Summary. Circulation, 101, 111116. http://dx.doi.org/10.1161/01.CIR.101.1.111

[9] Grundy, S.M., Bazzarre, T., Cleeman, J., D’Agostino, R.B., Hill, M., Houston-Miller, N., Kannel, W.B., Krauss, R., Krumholz, H.M., Lauer, R.M., Ockene, I.S., Pasternak, R.C., Pearson, T., Ridker, P.M. and Wood, D. (2000) Prevention Conference V: Beyond Secondary Prevention: Identifying the High-Risk Patient for Primary Prevention: Medical Office Assessment. Writing Group I. Circulation, 101, e3-e11. http://dx.doi.org/10.1161/01.CIR.101.1.e3

[10] Little, W.J., Miller, S.C., Henry, G.R. and McIntosh, B.A. (2002) Antithrombotic Agents: Implication in Dentistry. Oral Surgery, Oral Medicine, Oral Pathology and Oral Radiology, 93, 544-551. http://dx.doi.org/10.1067/moe.2002.121391

[11] Wang, X.K., Hsu, M.-Y., Steinbacher, T.E., Monticello, T.M. and Schumacher, W.A. (2007) Quantification of Platelet Composition in Experimental Venous Thrombosis by Real-Time Polymerase Chain Reaction. Thrombosis Research, 119, 593-600.

http://dx.doi.org/10.1016/j.thromres.2006.04.011

[12] Ahmed, A., Khan, R.A. and Mesaik, M.A. (2009) Anti-Inflammatory Effect of Natural Honey on Bovine Thrombin Induced Oxidative Burst in Phagocytes. Phytotherapy Research, 23, 801-808. http://dx.doi.org/10.1002/ptr.2648

[13] Riaz, A., Khan, R.A. and Ahmed, S.P. (2009) Assessment of Anticoagulant Effect of Evening Primrose Oil. Pakistan Journal of Pharmaceutical Sciences, 22, 355-359.

[14] Abdullah, W.Z., Moufak, S.K., Yusof, Z., Mohamad, M.S. and Kamarul, I.M. (2010) Shortened Activated Partial Thromboplastin Time, a Hemostatic Marker for Hypercoagulable State during Acute Coronary Event. Translational Research, 155, 315-319. http://dx.doi.org/10.1016/j.trsl.2010.02.001

[15] Heiss, C., Kleinbongard, P., Dejam, A., Perre, S., Schroeter, H., Sies, H. and Kelm, M. (2005) Acute Consumption of Flavanol-Rich Cocoa and the Reversal of Endothelial Dysfunction in Smokers. Journal of the American College of Cardiology, 46, 1276-1283. http://dx.doi.org/10.1016/j.jacc.2005.06.055

[16] McCullough, M.L., Peterson, J.J., Patel, R., Jacques, P.F., Shah, R. and Dwyer, J.T. (2012) Flavonoid Intake and Cardiovascular Disease Mortality in a Prospective Cohort of US Adults. American Journal of Clinical Nutrition, 95, 454-464. http://dx.doi.org/10.3945/ajcn.111.016634

[17] Kim, H.P., Son, K.H., Chang, H.W. and Kang, S.S. (2004) Anti-Inflammatory Plant Flavonoids and Cellular Action Mechanisms. Journal of Pharmacological Sciences, 96, 229-245. http://dx.doi.org/10.1254/jphs.CRJ04003X

[18] Chun, O.K., Chung, S.J., Claycombe, K.J. and Song, W.O. (2008) Serum C-Reactive Protein Concentrations Are Inversely Associated with Dietary Flavonoid Intake in US Adults. Journal of Nutrition, 138, 753-760.

[19] Grassi, D., Desideri, G. and Ferri, C. (2010) Flavonoids: Antioxidants against Atherosclerosis. Nutrients, 2, 889-902. http://dx.doi.org/10.3390/nu2080889

[20] Hernandez, M.V., Montes, M.M.A. and Elizalde, G.M.P. (2009) Study of the Thermal Degradation of Citrus Seeds. Biomass and Bioenergy, 33, 1295-1299.

http://dx.doi.org/10.1016/j.biombioe.2009.05.016 
[21] Gonzalez, M.E., Domínguez, P.R., Moreno, D.A. and García, V.C. (2010) Natural Bioactive Compounds of Citrus limon for Food and Health. Journal of Pharmaceutical and Biomedical Analysis, 51, 327-345. http://dx.doi.org/10.1016/j.jpba.2009.07.027

[22] Vazquez, P.R.L., Martinez, D.E., Perona, S.J. and Ruiz, G.V. (2004) Effect of Different Dietary Oils on Inflammatory Mediator Generation and Fatty Acid Composition in Rat Neutrophils. Metabolism, 53, 59-65. http://dx.doi.org/10.1016/j.metabol.2003.08.010

[23] Pfister, S.L. (2006) Aortic Thromboxane Receptor Deficiency Alters Vascular Reactivity in Cholesterol-Fed Rabbits. Atherosclerosis, 189, 358-363.

http://dx.doi.org/10.1016/j.atherosclerosis.2006.02.004

[24] Son, D.J., Lee, H.W., Shin, H.W., Lee, J.J., Yoo, H.S., Kim, T.J., Yun, Y.P. and Hong, J.T. (2008) Enhanced Release of Sphingosine-1-Phosphate from Hypercholesterolemic Platelets: Role in Development of Hypercholesterolemic Atherosclerosis. Prostaglandins, Leukotrienes and Essential Fatty Acids, 78, 383-390. http://dx.doi.org/10.1016/j.plefa.2008.04.010

[25] Giovannucci, E., Rimm, E.B., Liu, Y., Stampfer, M.J. and Willett, W.C. (2002) A Prospective Study of Tomato Products, Lycopene, and Prostate Cancer Risk. Journal of the National Cancer Institute, 94, 391-398. http://dx.doi.org/10.1093/jnci/94.5.391

[26] Gorinstein, S., Caspi, A., Libman, I., Lerner, H.T., Huang, D., Leontowicz, H., Leontowicz, M., Tashma, Z., Katrich, E., Feng, S. and Trakhtenberg, S. (2006) Red Grapefruit Positively Influences Serum Triglyceride Level in Patients Suffering from Coronary Atherosclerosis: Studies in Vitro and in Humans. Journal of Agricultural and Food Chemistry, 54, 18871892. http://dx.doi.org/10.1021/jf058171g

[27] Danckwardt, S., Hentze, M.W. and Kulozik, A.E. (2013) Pathologies at the Nexus of Blood Coagulation and Inflammation: Thrombin in Hemostasis, Cancer and Beyond. Journal of Molecular Medicine, 91, 1257-1271. http://dx.doi.org/10.1007/s00109-013-1074-5

[28] Di Cera, E. (2008) Thrombin Review. Molecular Aspects of Medicine, 29, 203-254. http://dx.doi.org/10.1016/j.mam.2008.01.001

[29] Merchant, M.A. and Modi, D.N. (2004) Acute and Chronic Effects of Aspirin on Hematological Parameters and Hepatic Ferritin Expression in Mice. Indian Journal of Pharmacology, 36, 226-230.

[30] Warfarin Dosing Guideline (2009) Guidelines Were Prepared by the Department of Surgical Education, Orlando Regional Medical Center. www.SurgicalCriticalCare.net

[31] Wayne, P.A. (1998) Collection, Transport and Processing of Blood Specimens for Coagulation Testing and General Performance of Coagulation Assays. 3rd Edition, Approved Guideline H21-A2, National Committee for Clinical Laboratory Standards, NCCLS Document H21-A3.

[32] Clauss, A. (1957) Rapid Physiological Coagulation Method in Determination of Fibrinogen. Acta Haematologica, 17, 237-246. http://dx.doi.org/10.1159/000205234

[33] McNerlan, S.E., Crawford, V.L. and Stout, R.W. (1997) Measurement of Fibrinogen in Frozen Plasma. Thrombosis Research, 88, 481-484. http://dx.doi.org/10.1016/S0049-3848(97)00283-1

[34] Kim, H.P., Park, H., Son, K.H., Chang, H.W. and Kang, S.S. (2008) Biochemical Pharmacology of Biflavonoids: Implications for Anti-Inflammatory Action. Archives of Pharmacal Research, 31, 265-273. http://dx.doi.org/10.1007/s12272-001-1151-3

[35] Jeon, S.M., Park, Y.B. and Choi, M.S. (2004) Antihypercholesterolemic Property of Naringin Alters Plasma and Tissue Lipids, Cholesterol-Regulating Enzymes, Fecal Sterol and Tissue Morphology in Rabbits. Clinical Nutrition, 23, 1025-1034.

http://dx.doi.org/10.1016/j.clnu.2004.01.006 
[36] Riaz, A., Khan, R.A. and Ahmed, M. (2013) Glycemic Response of Citrus limon. Pomegranate and Their Combinations in Alloxan Induced Diabetic Rats. Australian Journal of Basic and Applied Sciences, 7, 215-219.

[37] Bladbjerg, E.M., Marckmann, P., Sandstrom, B. and Jespersen, J. (1994) Non-Fasting Factor VII Coagulant Activity (FVII: C) Increased by High Fat Diet. Thrombosis and Haemostasis, 71, 755-778.

[38] Allman-Farinelli, M.A., Hall, D., Kingham, K., Pang, D., Petocz, P. and Favaloro, E.J. (1999) Comparison of the Effects of Two Low Fat Diets with Different $\alpha$ Linolenic: Linoleic Acid Ratios on Coagulation and Fibrinolysis. Atherosclerosis, 142, 159-168. http://dx.doi.org/10.1016/S0021-9150(98)00233-0

[39] Gentry, P.A. (2004) Comparative Aspects of Blood Coagulation. Veterinary Journal, 168, 238-251. http://dx.doi.org/10.1016/j.tvjl.2003.09.013

[40] Stanworth, S.J. (2007) The Evidence-Based Use of FFP and Cryoprecipitate for Abnormalities of Coagulation Tests and Clinical Coagulopathy. Hematology, 179-186.

[41] Miller, G.J. (2005) Dietary Fatty Acids and the Haemostatic System. Atherosclerosis, 179, 213-227. http://dx.doi.org/10.1016/j.atherosclerosis.2004.10.010

[42] Previtali, E., Bucciarelli, P., Passamonti, S.M. and Martinelli, I. (2011) Risk Factors for Venous and Arterial Thrombosis. Blood Transfusion, 9, 120-138.

[43] Monforte, M.T., Trovato, A., Kirjavainen, S., Forestieri, A.M., Galati, E.M. and Lo Curto, R.B. (1995) Biological Effects of Hesperidin, a Citrus flavonoid. (Note II): Hypolipidemic Activity on Experimental Hypercholesterolemia in Rat. Farmaco, 50, 595-599.

[44] Kelebek, H., Selli, S., Canbas, A. and Cabaroglu, T. (2009) HPLC Determination of Organic Acids, Sugars, Phenolic Compositions and Antioxidant Capacity of Orange Juice and Orange Wine Made from a Turkish cv. Kozan. Microchemical Journal, 91, 187-192. http://dx.doi.org/10.1016/j.microc.2008.10.008

[45] Violi, F., Pignatelli, P. and Basili, S. (2010) Nutrition, Supplements, and Vitamins in Platelet Function and Bleeding. Circulation, 121, 1033-1044. http://dx.doi.org/10.1161/CIRCULATIONAHA.109.880211

[46] Bojic, M., Debeljak, Z., Tomicic, M., Medic-Saric, M. and Tomic, S. (2011) Evaluation of Anti-Aggregatory Activity of Flavonoid Aglycone Series. Nutrition Journal, 10, 73. http://dx.doi.org/10.1186/1475-2891-10-73

[47] Chen, X., Li, W. and Wang, H. (2006) More Tea for Septic Patients?-Green Tea May Reduce Endotoxin-Induced Release of High Mobility Group Box 1 and Other Pro-Inflammatory Cytokines. Medical Hypotheses, 66, 660-603. http://dx.doi.org/10.1016/j.mehy.2005.09.025

[48] Teng, C.M., Li, H.L., Wu, T.S., Huang, S.C. and Huang, T.F. (1992) Antiplatelet Actions of Some Coumarin Compounds Isolated from Plant Sources. Thrombosis Research, 66, 549557. http://dx.doi.org/10.1016/0049-3848(92)90309-X 
Submit or recommend next manuscript to SCIRP and we will provide best service for you:

Accepting pre-submission inquiries through Email, Facebook, LinkedIn, Twitter, etc. A wide selection of journals (inclusive of 9 subjects, more than 200 journals)

Providing 24-hour high-quality service

User-friendly online submission system

Fair and swift peer-review system

Efficient typesetting and proofreading procedure

Display of the result of downloads and visits, as well as the number of cited articles

Maximum dissemination of your research work

Submit your manuscript at: http://papersubmission.scirp.org/

Or contact pp@scirp.org 